\title{
PERBEDAAN HASIL BELAJAR INSTALASI PENERANGAN LISTRIK MENGGUNAKAN STRATEGI PEMBELAJARAN PBL DENGAN STRATEGI PEMBELAJARAN EKSPOSITORI SISWA KELAS XI TIPTL SMK NEGERI 1 PERCUT SEI TUAN
}

\author{
${ }^{1}$ Abdul Hakim Butar-Butar, ${ }^{2}$ Muhammad Rasyid \\ Dosen Pendidikan Teknik Elektro, Fakultas Teknik, Universitas Negeri Medan \\ ${ }^{2}$ Guru Sekolah Menengah Kejuruan, \\ J1. Willem Iskandar Pasar V - Medan 20221 \\ $\frac{{ }^{1} \text { Abdulhakimbutar2@yahoo.com }}{2}$ \\ ${ }^{2}$ rasyidkarkun93@gmail.com
}

\begin{abstract}
ABSTRAK
Tujuan penenelitian ini adalah untuk mengetahui perbedaan hasil belajar mata pelajaran Instalasi Penerangan Listrik yang menggunakan strategi pembelajaran Problem Based Learning (PBL) dengan strategi pembelajaran Ekspositori Siswa Kelas XI TIPTL SMK Negeri 1 Percut Sei Tuan. Jenis penelitian ini merupakan penelitian quasi eksperimen. Populasi dalam penelitian ini adalah seluruh siswa kelas XI SMK SMK Negeri 1 Percut Sei Tuan Tahun Ajaran 2015/2016. Pengambilan sampel dilakukan dengan mengambil 2 kelas, yaitu kelas XI TIPTL 1 sebagai kelas eksperimen dan kelas XI TIPTL 2 sebagai kelas kontrol, yang masing-masing kelas berjumlah 32 orang siswa. Instrument yang digunakan untuk mengetahui hasil belajar siswa adalah tes hasil belajar dalam bentuk pilihan berganda dengan jumlah soal 30 butir. Hasil pengujian pretest sebelum diberi perlakuan yang berbeda, yaitu skor rata-rata di kelas eksperimen $(21,43)$ dengan standar deviasi 3,5 dan skor ratarata di kelas kontrol $(17,63)$ dengan standar deviasi 2,8 . Pada pengujian data pretest kedua kelas diperoleh bahwa data kedua kelas berdistribusi normal dan homogen yang berarti memiliki kemampuan awal yang sama. Kemudian diberi perlakuan yaitu kelas eksperimen diajarkan dengan strategi pembelajaran Problem Based Learning (PBL) dan kelas kontrol diajar dengan strategi pembelajaran Ekspositori. Setelah pembelajaran selesai diberikan posttest, diperoleh nilai posttest dengan hasil rata-rata kelas eksperimen $(82,19)$ dengan standar deviasi 8,76 dan kelas kontrol $(69,38)$ dengan standar deviasi 12,68.
\end{abstract}

Kata Kunci: Hasil Belajar, strategi pembelajaran Problem Based Learning (PBL), strategi Pembelajaran Ekspositori

\section{PENDAHULUAN}

Pendidikan merupakan salah satu faktor yang sangat berpengaruh untuk meningkatkan kualitas suatu bangsa dan negara, karena melalui pendidikan harkat dan martabat bangsa dapat meningkat. Dimana pendidikan merupakan sarana untuk pengembangan Sumber Daya Manusia. Di sisi lain, pendidikan juga merupakan modal utama dalam pembangunan bangsa. Melalui peningkatan mutu pendidikan, diharapkan dapat menghasilkan manusia yang berkontribusi bagi masyarakat, bangsa, dan negara yang kompeten di era globalisasi.

Pendidikan memegang peranan penting dalam menghasilkan Sumber Daya Manusia yang berkompeten, karena dalam pendidikanlah individu diproses menjadi manusia yang handal. Menurut Buchori (2001) dalam Trianto (2011: 4) mengatakan, bahwa pendidikan yang baik adalah pendidikan yang tidak hanya mempersiapkan para siswanya untuk suatu profesi atau jabatan, tetapi juga untuk menyelesaikan masalah-masalah yang dihadapinya dalam 
kehidupan sehari-hari. Selanjutnya, masalah pendidikan tersebut dapat diakibatkan oleh beberapa faktor. Slameto (2010: 54) menggolongkannya menjadi dua, yaitu faktor internal dan faktor eksternal, dimana faktor internal yaitu: (1). Faktor jasmani, (2). Faktor psikologis, (3). Faktor kelelahan. Sedangkan faktor eksternal diantaranya: (1). Faktor keluarga, (2). Faktor sekolah, (3). Faktor masyarakat.

Sementara itu, hasil belajar merupakan perubahan tingkah laku yang terjadi pada siswa setelah mengalami proses pembelajaran. Sebagaimana hal ini dinyatakan oleh Bloom dalam Suprijono (2010: 6) bahwa hasil belajar dapat diklasifikasikan ke dalam 3 kawasan yaitu kawasan kognitif, kawasan afektif, dan psikomotorik.

Sekolah Menengah Kejuruan (SMK) merupakan salah satu lembaga pendidikan yang bertujuan untuk mempersiapkan lulusannya memasuki dunia kerja yang mempunyai pengetahuan dan bertanggung jawab dalam pekerjaannya sesuai dengan bidangnya. Hal ini sesuai dengan pasal 11 ayat 3 Undang-Undang No 2 tahun 1989 tentang pendidikan nasional yang menyebutkan bahwa pendidikan kejuruan merupakan pendidikan yang mempersiapkan siswa untuk dapat bekerja pada bidang tertentu. Untuk mencapai tujuan tersebut, pembinaan siswa yang akan terjun ke masyarakat harus dilakukan seoptimal mungkin, baik mengenai kompetensi kejuruan, sikap dalam bermasyarakat maupun bidang disiplin ilmu.

Lebih lanjut, hal tersebut senada dengan tujuan SMK dalam GBPP (Depdiknas, 2004: 6), yaitu: (1) Menyiapkan siswa untuk memasuki lapangan kerja serta mengembangkan sikap profesionalisme, (2) Menyiapkan siswa agar mampu memilih karir, mampu berkompetensi dan mampu mengembangkan diri, (3) Menyiapkan tenaga kerja tingkat menengah untuk mengisi kebutuhan dunia usaha dan industri baik pada saat ini maupun pada saat yang akan datang, (4) Menyiapkan lulusan agar mampu menjadi warga negara yang produktif, adaptif, dan kreatif.

Senada dengan hal tersebut di atas, Sekolah Menengah Kejuruan diharapkan dapat menghasilkan tenaga yang terampil dan berkualitas serta menguasai bidang yang digelutinya, sehingga kebutuhan dunia usaha dan industri dapat terpenuhi. Untuk mencapai hal tersebut, siswa Sekolah Menengah Kejuruan dituntut untuk lebih memahami dan menguasai setiap mata pelajaran yang diterimanya di sekolah, karena setiap mata pelajaran saling mempengaruhi dan saling mendukung pada peningkatan pengetahuan, keterampilan, perkembangan sikap dan kepribadiannya.

SMK Negeri 1 Percut Sei Tuan adalah salah satu lembaga pendidikan formal di bidang keteknikan, dimana para lulusannya diharapkan mampu bersaing dalam DU/DI. Namun, berdasarkan hasil observasi yang dilaksanakan peneliti di SMK Negeri 1 Percut Sei Tuan, bahwa nilai yang diperoleh siswa pada mata pelajaran Instalasi Penerangan Listrik kelas XI Teknik Instalasi Pemanfaatan Tenaga Listrik (TIPTL) tahun ajaran 2014/2015 menunjukkan masih berada di bawah standar rata-rata yang ditetapkan oleh Depdiknas, dimana nilai KKM untuk mata diklat produktif yaitu sebesar 75. Sementara itu, nilai rata-rata yang diperoleh siswa berdasarkan data dari Daftar Kumpulan Nilai (DKN) siswa kelas XI (TIPTL) untuk mata pelajaran Instalasi Penerangan Listrik pada tahun ajaran 2014/2015 hanya sebesar 68,78. Selanjutnya, dari hasil tanya jawab dengan beberapa siswa mengungkapkan bahwa mereka mengalami kesulitan untuk memahami materi pelajaran Instalasi Penerangan Listrik dan mereka kurang bersemangat ketika belajar.

Lebih lanjut lagi, hasil diskusi peneliti dengan Pak Fakhriza Marta Tanjung, selaku kepala bengkel Teknik Instalasi Pemanfaatan Tenaga Listrik (TIPTL) SMK Negeri 1 Percut Sei Tuan mengungkapkan bahwa sampai saat ini kegiatan pembelajaran yang dilaksanakan masih didominasi oleh guru (ekspositori). Dimana guru bidang studi 
Instalasi Penerangan Listrik pun masih menggunakan strategi pembelajaran yang didominasi oleh guru. Hal ini menyebabkan siswa kurang diberikan akses untuk berkembang secara mandiri, karena lebih diarahkan pada kemampuan siswa untuk menghapal pelajaran tanpa dituntut untuk memahami pelajaran tersebut sehingga siswa menjadi pasif di dalam kelas. Hal ini sejalan dengan pendapat Slameto (2010: 65) yang mengungkapkan bahwa strategi ekspositori merupakan strategi pembelajaran dengan strategi ceramah, sehingga siswa menjadi bosan, mengantuk, pasif, dan hanya mencatat saja. Meskipun demikian, guru lebih suka menerapkan strategi ekspositori karena tidak memerlukan alat dan bahan praktek, cukup menjelaskan konsep-konsep yang ada dalam buku ajar atau referensi lain (Trianto, 2011: 6). Proses ini hanya menekankan pada pencapaian tuntutan kurikulum dari pada pengembangan kemampuan belajar siswa. Guru senantiasa dikejar oleh target waktu untuk menyelesaikan setiap pokok bahasan tanpa memperhatikan kompetensi yang dimiliki siswanya. Kurangnya keterlibatan siswa dalam proses pembelajaran dapat mengakibatkan hasil belajar siswa menjadi rendah karena peran siswa tidak lagi sebagai subyek belajar melainkan sebagai objek pembelajaran.

Rendahnya hasil belajar yang dialami oleh siswa dapat disebabkan oleh beberapa faktor, menurut Muhibbin Syah (2009) dalam Hendriantika (2013: 4) mengemukakan bahwa faktor-faktor yang dapat mempengaruhi belajar siswa dapat dibedakan menjadi 3 (tiga) golongan, yaitu: (1) Faktor Internal (faktor dari dalam diri siswa), yakni keadaan/kondisi jasmani dan rohani siswa, (2) Faktor Eksternal (faktor dari luar diri siswa), yakni kondisi lingkungan di sekitar diri siswa, (3) Faktor pendekatan belajar (approach to learning), yakni jenis upaya belajar siswa yang meliputi strategi dan model yang digunakan siswa untuk melakukan kegiatan pembelajaran, sehingga sebagian besar hasil belajar siswa tidak mencapai nilai batas ketuntasan belajar yang ditetapkan.
Berdasarkan beberapa faktor yang dapat mengakibatkan hasil belajar siswa kurang memuaskan dan gambaran ketidakberhasilan siswa dalam belajar, maka guru perlu menerapkan strategi pembelajaran yang dapat membantu meningkatkan kemampuan siswa dalam mengembangkan, menemukan, menyelidiki, bekerja memecahkan masalah, dan mengungkapkan ide sendiri serta saling mendiskusikan masalah-masalah tersebut dengan temannya.

Dalam upaya peningkatan hasil belajar Instalasi Penerangan Listrik perlu diadakan suatu inovasi pembelajaran di SMK Negeri 1 Percut Sei Tuan. Dimana pada kesempatan kali ini peneliti akan menawarkan suatu alternatif berupa strategi pembelajaran yang dapat digunakan oleh guru adalah dengan menggunakan strategi Pembelajaran Berbasis Masalah. Sebagaimana menurut Arends (1997) dalam Trianto (2011 : 92) menyatakan bahwa strategi Problem Based Learning merupakan strategi pembelajaran siswa pada masalah nyata, sehingga siswa dapat menyusun pengetahuannya sendiri, mengembangkan keterampilan dan inkuiri yang tinggi, memandirikan siswa, dan meningkatkan kepercayaan dirinya. Strategi pembelajaran Berbasis Masalah menempatkan siswa pada keterlibatannya di dalam proses belajar mengajar dan membiasakan siswa untuk lebih aktif serta dapat menghubungkan pengetahuan yang dimiliki dan penerapannya dalam kehidupan sehari-hari.

Berdasarkan uraian di atas, dapat ditarik kesimpulan bahwa dalam pencapaian hasil belajar diperlukan beberapa strategi pembelajaran yang sesuai dengan materi dan siswa.

\section{KAJIAN PUSTAKA}

Belajar adalah aktivitas mental/psikis yang berlangsung dalam interaksi aktif dengan lingkungan yang menghasilkan perubahan - perubahan dalam pengetahuan, keterampilan, dan sikap(Winkel, 1999:53). Menurut Sudjana (1989) dalam Rusman (2011: 1) mengatakan bahwa belajar merupakan proses melihat, mengamati, dan 
memahami sesuatu. Selanjutnya, menurut Sanjaya (2006: 57) belajar adalah proses perubahan tingkah laku. Lebih lanjut lagi, Sanjaya (2006: 110) mengemukakan, bahwa proses belajar adalah terus-menerus, yang tidak pernah berhenti dan tidak terbatas pada dinding kelas, oleh karena itu belajar bisa kapan saja dan dimana saja. Hal ini dipertegas oleh Trianto (2011: 9) yang mengatakan, bahwa belajar adalah adanya perubahan tingkah laku karena adanya suatu pengalaman. Perubahan tingkah laku tersebut dapat berupa perubahan keterampilan, kebiasaan, sikap, pengetahuan, pemahaman dan apresiasi. Pengalaman dalam proses belajar adalah bentuk interaksi antara individu dengan lingkungan.

Hasil belajar merupakan hasil dari suatu interaksi tindak belajar dan tindak mengajar (Dimyati dan Mudjiono, 2002: 3). Selanjutnya, menurut Suprijono (2010: 7) mengemukakan bahwa hasil belajar adalah perubahan perilaku secara keseluruhan bukan hanya salah satu aspek potensi kemanusiaan saja. Lebih lanjut lagi, menurut pendapat Keller sebagaimana dikutip Abdurrahman (2003) dalam Hanif (2014: 9) mengemukakan, bahwa hasil belajar adalah proses aktual yang ditampilkan oleh anak, sedangkan usaha adalah perbuatan yang terarah pada penyelesaian tugas-tugas belajar. Dengan demikian, hasil belajar dipengaruhi oleh besarnya usaha yang dicurahkan, intelegensi, kesempatan yang diberikan kepada anak untuk mengembangkan dirinya, yang pada akhirnya akan mempengaruhi hasil belajar.

Secara umum, hasil belajar adalah hasil dari kemampuan seseorang yang berprestasi dalam belajar. Sedangkan menurut Sudjana (1989) menyatakan, bahwa hasil belajar adalah kemampuan-kemampuan yang dimilki siswa setelah ia menerima pengalaman belajarnya.

Sementara itu, menurut Dimyati dan Mudjiono (2002) mengungkapkan, bahwa hasil belajar adalah ukuran atau tingkat keberhasilan yang dapat dicapai oleh seorang siswa berdasarkan pengalaman yang diperoleh setelah dilakukan evaluasi berupa tes dan biasanya diwujudkan dengan nilai atau angka-angka tertentu serta menyebabkan terjadinya perubahan kognitif, afektif, maupun psikomotorik. Untuk mencapai hal tersebut, maka para siswa harus siap untuk menerima pembelajaran serta dibarengi dengan ketekunan, keuletan dan kegigihan untuk belajar.

Benjamin S. Bloom dalam Dimyati dan Mudjiono (2002: 26) membagi sasaran hasil belajar menjadi 3 ranah yaitu: ranah kognitif, afektif dan psikomotorik. Ketiga ranah tersebut menjadi objek penilaian hasil belajar. Diantara ketiga ranah tersebut, ranah kognitiflah yang paling banyak dinilai oleh para guru di sekolah karena berkaitan dengan kemampuan para siswa dalam menguasai materi pembelajaran.

Instalasi Penerangan Listrik merupakan mata pelajaran dalam Kurikulum 2013 untuk siswa kelas XI. Dimana pelajaran ini merupakan kompetensi dalam program keahlian Teknik Instalasi Pemanfaatan Tenaga Listrik. Mengingat mata pelajaran Instalasi Penerangan Listrik di SMK Negeri 1 Percut Sei Tuan yang terdiri dari beberapa standar kompetensi dan setiap standar kompetensi terdiri dari beberapa kompetensi dasar, maka yang menjadi standar kompetensi dan kompetensi dasar dalam penelitian ini adalah memahami instalasi penerangan satu fasa.

Hasil belajar yang diperoleh siswa melalui proses pembelajaran dapat diketahui melalui evaluasi hasil belajar yang dapat dilakukan melalui seperangkat tes yang yang disusun sesuai dengan materi pelajaran yang diberikan. Hasil belajar menggambarkan tingkat keberhasilan siswa dalam proses belajar mengajar yang dilaksanakan.

Secara umum, strategi adalah suatu garis besar acuan dalam melakukan tindakan untuk mencapai sasaran yang diinginkan (Ngalimun, 2013: 1). Lebih lanjut lagi, Ngalimun (2013: 1) mengemukakan bahwa strategi pembelajaran dapat diartikan sebagai pola umum kegiatan antara guru dan murid dalam suatu kegiatan belajar mengajar untuk mencapai tujuan yang telah digariskan. Sementara itu, Sanjaya (2006: 126) 
menjelaskan, bahwa strategi pembelajaran adalah perencanaan yang berisi tentang rangkaian kegiatan yang didesain untuk mencapai tujuan pendidikan tertentu. Lebih lanjut, menurut Kemp (1995) dalam La Iru (2012: 5) menjelaskan, bahwa strategi pembelajaran adalah suatu kegiatan pembelajaran yang harus dikerjakan oleh guru dan siswa agar tujuan pembelajaran dapat dicapai secara efektif dan efisien. Senada dengan pendapat tersebut, Dick dan Carey (1985) dalam La Iru (2012: 5) juga menyebutkan bahwa strategi pembelajaran itu adalah suatu set materi dan prosedur pembelajaran yang digunakan secara bersama-sama untuk menimbulkan hasil belajar dan siswa.

Di sisi lain, Gerlach dan Ely dalam Ngalimun (2013: 5) menjelaskan bahwa strategi pembelajaran merupakan cara-cara yang dipilih untuk menyampaikan materi pembelajaran dalam lingkungan pembelajaran tertentu. Strategi pembelajaran dimaksud meliputi; sifat, lingkup, dan urutan kegiatan pembelajaran yang dapat memberikan pengalaman belajar kepada peserta didik. Sementara itu, Cropper dalam Ngalimun (2013: 6) mengatakan bahwa strategi pembelajaran merupakan pemilihan atas berbagai jenis latihan tertentu yang sesuai dengan tujuan pembelajaran yang ingin dicapai.

Selanjutnya, La Iru (2012: 6) menerangkan bahwa ada dua hal yang patut dicermati dari pengertian di atas, yaitu Pertama, strategi pembelajaran merupakan rencana tindakan atau rangkaian kegiatan termasuk penggunaan metode dan pemanfaatan berbagai sumber daya baik kekuatan maupun kelemahan dalam pembelajaran. Ini berarti penyusunan suatu strategi baru sampai pada proses penyusunan rencana kerja belum sampai pada tindakan. Kedua, strategi disusun untuk mencapai tujuan tertentu, artinya arah dari semua keputusan penyusunan strategi adalah pencapaian tujuan/kompetensi.

Problem Based Learning pertama kali diperkenalkan pada awal tahun 1970-an di Universitas Mc Master Fakultas Kedokteran
Kanada, sebagai satu upaya menemukan solusi dalam diagnosis dengan membuat pertanyaan-pertanyaan sesuai situasi yang ada (Rusman, 2011 : 242). Selanjutnya, Rusman (2011: 229) menjelaskan bahwa, Problem Based Learning atau pembelajaran berbasis masalah merupakan inovasi dalam pembelajaran karena dalam pembelajaran berbasis masalah, kemampuan berpikir siswa betul-betul dioptimalkan melalui proses kerja kelompok atau tim yang sistematis, sehingga siswa dapat memberdayakan, mengasah, menguji, dan mengembangkan kemampuan berpikirnya secara berkesinambungan.

\section{Sementara itu, Boud dan Feletti} (1997) dalam Rusman (2011: 230) mengemukakan bahwa Pembelajaran berbasis masalah adalah inovasi yang paling signifikan dalam pendidikan. Di sisi lain, Margetson (1994) dalam Rusman (2011: 230) mengemukakan bahwa dalam kurikulum pembelajaran berbasis masalah membantu untuk meningkatkan perkembangan keterampilan belajar sepanjang hayat dalam pola pikir yang terbuka, reflektif, kritis, dan belajar aktif. Lebih lanjut lagi, menurut John Dewey sebagaimana dikutip Arends, (2008) dalam La Iru (2012: 58) mendeskripsikan pandangan tentang pendidikan dengan sekolah sebagai cermin masyarakat yang lebih besar dan kelas menjadi laboratorium untuk penyelidikan dan penuntasan masalah kehidupan nyata.

Strategi pembelajaran Ekspositori adalah strategi pembelajaran yang menekankan kepada proses penyampaian materi secara verbal dari seseorang guru kepada sekelompok siswa dengan maksud agar siswa dapat menguasai materi pelajaran secara optimal (Sanjaya, 2006: 179). Sementara itu, menurut La Iru, (2012: 41) mengatakan bahwa strategi pembelajaran Ekspositori adalah strategi pembelajaran yang lebih berorientasi pada guru dalam arti bahwa semua pesan pembelajaran yang diharapkan untuk dikuasai oleh siswa telah diolah dalam bentuk barang jadi oleh guru dan selanjutnya disampaikan pada siswa. 
Senada dengan hal di atas, Sanjaya (2006: 179) menjelaskan bahwa strategi pembelajaran ekpositori merupakan bentuk dari pendekatan pembelajaran yang berorientasi kepada guru (teacher centered approach). Dalam strategi Ekspositori ini guru memegang peranan yang sangat dominanan, dan melalui strategi ini guru menyampaikan materi pembelajaran secara terstruktur dengan harapan materi pelajaran yang disampaikan itu dapat dikuasai siswa dengan baik. Lebih lanjut lagi, Sanjaya (2006: 179) mengemukakan bahwa ada beberapa karakteristik strategi pembelajaran Ekspositori. Pertama, Ekspositori dilakukan dengan cara menyampaikan materi pelejaran secara verbal artinya bertutur secara lisan yang merupakan alat utama dalam melakukan strategi ini. Oleh karena itu strategi Ekspositori ini diidentikkan dengan ceramah. Kedua, biasanya materi pelajaran yang disampaikan adalah materi pelajaran yang sudah jadi seperti data atau fakta, konsep-konsep tertentu yang harus dihafal sehingga tidak menuntut siswa untuk berfikir ulang. Ketiga, tujuan utama pembelajaran adalah penguasaan materi pelajaran itu sendiri, artinya setelah proses pembelajaran berakhir siswa diharapkan dapat memahaminya dengan benar dengan cara dapat mengungkapkan kembali materi yang telah diuraikan.

\section{METODE PENELITIAN}

Penelitian ini dilaksanakan di SMK Negeri 1 Percut Sei Tuan, Jln. Kolam No. 3 Medan Estate. Waktu penelitian akan dilaksanakan pada siswa kelas XI Teknik Instalasi Pemanfaatan Tenaga Listrik (TIPTL) pada tahun ajaran 2015/2016.

Variabel dalam penelitian ini ada dua jenis, yaitu variable bebas dan variabel terikat. Variabel bebas adalah yang dapat dimanipulasi atau dapat dijadikan sebagai bentuk perlakuan, sedangkan variabel terikat adalah hasil akibat dari pengaruh variabel bebas. Populasi dalam penelitian ini adalah seluruh siswa kelas XI TIPTL program keahlian Teknik Instalasi Pamanfaatan Tenaga Listrik SMK Negeri 1 Percut Sei
Tuan Tahun Ajaran 2015/2016 yang terdiri dari 2 kelas, dimana kelas XI TIPTL $^{1}$ jumlahnya 32 siswa dan kelas XI TIPTL ${ }^{2}$ jumlahnya 33 siswa. Pengambilan sampel menggunakan teknik Total Sampling karena jumlah populasi terdiri dari 2 kelas yang totalnya 65 siswa, akhirnya menjadi sampel penelitian yaitu kelas eksperimen XI TIPTL ${ }^{1}$ diajar dengan menggunakan strategi pembelajaran Problem Based Learning (PBL). Kelas kontrol XI TIPTL $^{2}$ diajar dengan menggunakan Penelitian ini bersifat penelitian quasi eksperimen, yang melibatkan dua kelas yang diberi perlakuan yang berbeda. Desain penelitian yang digunakan dalam penelitian ini adalah Pretest Post-test control Group Desain yaitu dengan melihat perbedaan hasil belajar (post test) antara kelompok eksperimen dan kontrol (Arikunto, 2009: 210).

Dalam mengumpulkan data untuk hasil belajar siswa menggunakan tes hasil belajar siswa pada materi instalasi penerangan satu fasa. Tes ini berbentuk pilihan berganda sebanyak 30 soal dengan empat pilihan berganda. Dalam penyusunan tes ini digunakan dari kumpulan materi pelajaran. Kriteria penilaian adalah memberikan skor 1 untuk setiap soal yang dijawab benar dan skor 0 untuk setiap soal yang dijawab salah.

Setelah tes hasil belajar disusun, sebelum digunakan untuk menjaring data penelitian terlebih dahulu diuji cobakan untuk melihat kesahihan dan keterandalan butir tes dengan cara yaitu uji coba instrumen. Uji coba ini juga bertujuan untuk mendapatkan alat ukur yang benar-benar dapat menjaring data yang akurat agar kesimpulan yang diambil sesuai dengan kenyataan. Sebelum pengumpulan data dilakukan, terlebih dahulu dilakukan uji coba instrumen penelitian yang dilaksanakan di SMK Negeri 1 Percut Sei Tuan pada kelas XII Program Keahlian Teknik Instalasi Pemanfaatan Tenaga Listrik.

Data uji coba intrumen yang diperoleh akan dianalisa dengan langkah-langkah sebagai berikut: (1) Validitas test, (2) Reabilitas test, (3) Indeks kesukaran soal. dan (4) Daya pembeda. 
Langkah-langkah diatas sebagai acuan dari penilaian yang dilakukan untuk selanjutnya melihat kelayakan dari instrumen yang akan digunakan dalam penelitian.

\section{HASIL DAN PEMBAHASAN}

Berdasarkan tes hasil belajar yang diberikan setelah proses pemberian perlakuan dengan strategi pembelajaran Problem Based Learning (PBL) diperoleh rata-rata skor $=24,66 ;$ Varians $=6,91$; Standar Deviasi $=2,629$; skor tertinggi $=29$; skor terendah $=17$ dengan jumlah sample $=$ 32 orang. Dengan menggunakan teknik Sturges didapatkan banyak kelas 5 dan panjang kelas 3, maka daftar distribusi frekuensi mengenai hasil belajar yang diajar dengan strategi PBL dapat dilihat pada tabel 1 di bawah ini:

Tabel 1. Distribusi Frekuensi Skor hasil belajar siswa yang diajar dengan menggunakan strategi Problem Based Learning (PBL)

\begin{tabular}{|l|l|l|l|}
\hline Kelas & Interval & Fo & Fr (\%) \\
\hline 1 & $17-19$ & 2 & 6,250 \\
\hline 2 & $20-22$ & 2 & 6,250 \\
\hline 3 & $23-25$ & 17 & 53,125 \\
\hline 4 & $26-28$ & 9 & 28,125 \\
\hline 5 & 29 & 2 & 6,250 \\
\hline Jumlah & 32 & 100 \\
\hline
\end{tabular}

Dari tabel 1 di atas, dapat dilihat distribusi frekuensi skor hasil belajar siswa yang diajar menggunakan strategi PBL. Untuk lebih jelasnya, dapat dilihat pada gambar 1 di bawah ini,

Berdasarkan gambar 1, siswa yang mendapat skor antara 17-19 ada sebanyak 2 orang, antara 20-22 ada sebanyak 2 orang, antara 23-25 ada sebanyak 17 orang, antara 26-28 ada sebanyak 9 orang, dan skor 29 ada sebanyak 2 orang. Jika skor yang diperoleh siswa diubah jadi nilai, maka dari 32 siswa ada sebanyak 4 orang yang mendapat nilai di bawah 75 dan 28 orang mendapat nilai di atas 75 .

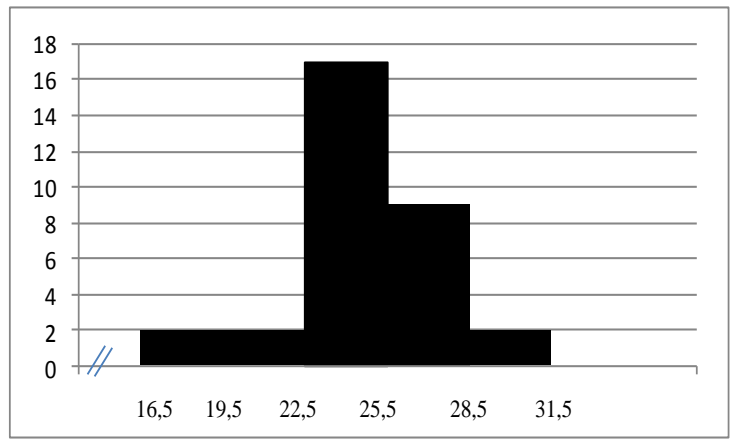

Gambar 1. Histogram Hasil Belajar siswa yang diajar dengan menggunakan strategi Problem Based Learning (PBL)

Berdasarkan tes hasil belajar yang diberikan setelah proses pemberian perlakuan dengan menggunakan strategi pembelajaran Ekspositori diperoleh rata-rata skor $=20,81$; varians $=14,46$; standar deviasi $=3,803$, skor tertinggi $=27$ dan skor terendah $=14$ dengan jumlah sampel 32 siswa. Dengan menggunakan teknik Sturges didapatkan banyak kelas 5 dan panjang kelas 3 , maka daftar distribusi frekuensi mengenai hasil belajar yang diajar dengan strategi Ekspositori dapat dilihat pada Tabel $4.3 \mathrm{di}$ bawah ini :

\section{Tabel 2. Distribusi Frekuensi Skor Hasil}

Belajar Siswa Yang Diajar Dengan

Menggunakan Strategi Pembelajaran Ekspositori

\begin{tabular}{|c|c|c|c|}
\hline Kelas & Interval & Fo & $\operatorname{Fr}(\%)$ \\
\hline 1 & $14-16$ & 6 & 18,750 \\
\hline 2 & $17-19$ & 6 & 18,750 \\
\hline 3 & $20-22$ & 7 & 21,875 \\
\hline 4 & $23-25$ & 10 & 31,250 \\
\hline 5 & $26-28$ & 3 & 9,375 \\
\hline \multicolumn{2}{|c|}{ Jumlah } & 32 & 100 \\
\hline
\end{tabular}

Dari tabel 2 di atas, dapat dilihat distribusi frekuensi skor hasil belajar siswa yang diajar menggunakan strategi Ekspositori. Untuk lebih jelasnya, dapat dilihat pada gambar 2 di bawah ini : 


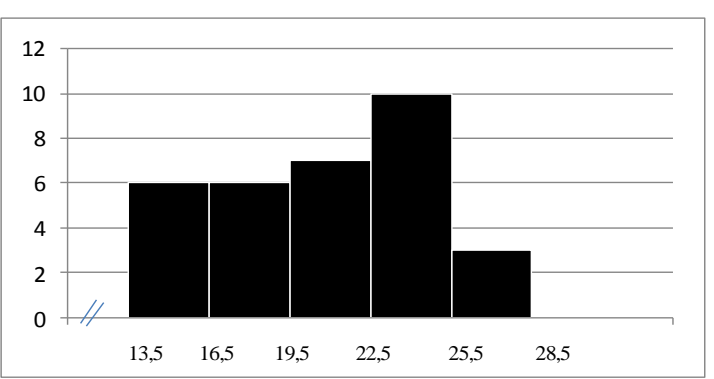

Gambar 2 Histogram Hasil Belajar siswa yang diajar dengan menggunakan strategi Ekspositori

Berdasarkan gambar.2 di atas, siswa yang mendapat skor antara 14-16 ada sebanyak 6 orang, antara 17-19 ada sebanyak 6 orang, antara 20-22 ada sebanyak 7 orang, antara 23-25 ada sebanyak 10 orang, dan skor antara 26-28 ada sebanyak 3 orang. Jika skor yang diperoleh siswa diubah jadi nilai, maka dari 32 siswa ada sebanyak 19 orang yang mendapat nilai di bawah 75 dan 13 orang mendapat nilai di atas 75 .

Sebelum dilakukan analisis data untuk menguji hipotesis, maka data yang diperoleh terlebih dahulu diuji normalitas dan homogenitasnya dengan menggunakan data posttest.

Analisis tahap akhir menunjukkan data hasil belajar kelas eksperimen dan kelas kontrol berdistribusi normal karena $\mathrm{L}_{\text {hitung }}$ untuk setiap data kurang dari $\mathrm{L}_{\text {tabel }}$. Hasil uji kesamaan varians data hasil belajar kelas eksperimen dan kelas kontrol diperoleh $F_{\text {hitung }}(1,19)<F_{\text {tabel }}(1,93)$ sehingga dapat disimpulkan bahwa kedua kelompok mempunyai variansi yang sama (homogen).

Berdasarkan uji hipotesis yang telah dilakukan, diperoleh $t_{\text {hitung }}=4,718$ sedangkan $t_{\text {table }}=1,6749$. Karena $t_{\text {hitung }}>$

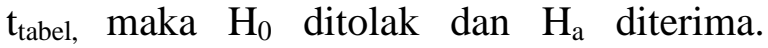
Dengan demikian dapat disimpulkan bahwa hasil belajar Instalasi Penerangan Listrik siswa yang diajar dengan menggunakan Strategi Pembelajaran Problem Based Learning (PBL) lebih tinggi dari pada siswa yang diajar dengan menggunakan Strategi Pembelajaran Ekspositori siswa kelas XI Teknik Instalasi Pemanfaatan Tenaga Listrik (TIPTL) SMK Negeri 1 Percut Sei Tuan.
Setelah melakukan analisis data tingkat kecendrungan variabel penelitian maka untuk kelas Eksperimen dinyatakan bahwa siswa yang memiliki nilai berkategori tinggi sebanyak 28 orang dan siswa yang memiliki nilai berkategori cukup sebanyak 4 orang. Sedangkan, untuk kelas Kontrol dinyatakan bahwa siswa yang memiliki berkategori tinggi sebanyak 13 orang, siswa yang memiliki nilai berkategori cukup sebanyak 17 orang, dan siswa yang memiliki nilai berkategori kurang sebanyak 2 orang.

\section{KESIMPULAN}

Berdasarkan hasil penelitian diketahui bahwa hasil belajar Instalasi Penerangan Listrik siswa yang diajar dengan menggunakan Strategi Pembelajaran Problem Based Learning (PBL) lebih tinggi dari pada siswa yang diajar dengan menggunakan Strategi Pembelajaran Ekspositori siswa kelas XI Teknik Instalasi Pemanfaatan Tenaga Listrik (TIPTL) SMK Negeri 1 Percut Sei Tuan.

\section{DAFTAR PUSTAKA}

Arends, Richardl. (2008). Learning to Teach. Yogyakarta : Pustaka Pelajar.

Arikunto, Suharsimi. (2009). Managemen Penelitian. Jakarta : Rineka Cipta.

Bekti Wulandari.(2013). Pengaruh Problem Based Learning terhadap hasil belajar ditinjau dari motivasi belajar PLC di SMK. Hasil Penelitian, Semarang : Depdikbud

Depdiknas.(2004). Pedoman Penyelenggaraan Progaram Kecakapan Hidup (Life Skills) Pendidikan Non Formal. Jakarta : Ditjen. Diklusepa.

Dimyati dan Mudjiono (2002). Belajar dan Pembelajaran. Jakarta : Rineka Cipta.

Erlina.(2010). Pengaruh strategi pembelajaran berbasis masalah dan peta pikiran terhadap hasil belajar biologi siswa di SMA Negeri 1 Merbau. Hasil Penelitian. Medan : Lembaga Penelitian. 
Hanif. (2014).Penerapan konseling kelompok behavior untuk meningkatkan kedisplinan siswa di sekolah SMA Negeri 1 Kedungadem. Bojonegoro. Jurnal BK FIP UNESA.

Hendriantika, Rinda. (2013). Pengaruh sikap siswa pada mata pelajaran akuntansi terhadap hasil belajar siswa di SMA negeri 7 Tasikmalaya tahun ajaran 2011/2012. Skripsi. Bandung : FPBE UPI.

Hosnan M. (2014). Pendekatan Saintifik Dan Kontekstual Dalam Pembelajaran Abad 21. Jakarta : Ghalia Indonesia

I. Kd. Urip Astika, I. K. Suma dan I. W. Suastra .(2013). Pengaruh model pembelajaran berbasis masalah terhadap sikap ilmiah dan keterampilan berpikir kritis. Hasil Penelitian, tidak diterbitkan, Jakarta : Depdikbud.

Ibnu Toib.(2011). Pengaruh model pembelajaran problem based learning dan eksositori terhadap prestasi beajar pendidikan kewarganegaraan ditinjau dari motivasi mahasiswa program studi pendidikan matematika STKIP PGRI Lumajang. Hasil Penelitian. Surabaya : Lembaga Penelitian.

Istarani (2012). $58 \quad$ Model PembelajaranInovatif. Medan : Media Persada.

La Iru (2012). Analisi Penerapan Pendekatan, Metode, Strategi, dan Model. Jakarta :

Nelson Sinaga.(2013). Pengaruh strategi pembelajaran problem based learning terhadap hasil belajar merakit personal computer pada siswa kelas $\mathrm{X}$ teknik komputer jaringan di SMK Negeri 1 Tanjung Pura. Hasil Penelitian. Medan : Lembaga Penelitian.

Ngalimun (2013). Strategi dan Model Pembelajaran. Yogyakarta : Aswaja Pressindo.

Nur, M. (2011). Pembelajaran Berdasarkan Masalah. Surabaya : PSMS Unesa.
Purwanto (2008). Evaluasi Hasil Belajar. Yogyakarta : Pustaka Pelajar.

Rostiyah, N.K. (2008). Strategi Belajar Mengajar. Jakarta : Rineka cipta.

Rusman (2011). Model-model Pembelajaran. Jakarat : PT Raja Grafindo Persada.

Rusmono dan M. Yusro.(2009). Pengaruh strategi pembelajaran dan kecemasan terhadap hasil belajar matematika. Hasil Penelitian, tidak diterbitkan, Jakarta : Depdikbud.

Sanjaya (2006). Strategi Pembelajaran Berorientasi Standar Proses Pendidikan, Jakarta : Kencana

Slameto (2010). Belajar dan Faktor-faktor Yang Mempengaruhinya. Jakarta : Rineka Cipta Percival. Fred (1988). Teknologi Pendidikan, Jakarta : Erlangga.

Sudjana (1989). Penilaian Hasil Proses Hasil Belajar Mengajar. Bandung : PT Remaja rosdakarya

Sudjana (2008). Penghantar Statistika. Bandung: PT. Tarsito

Sudjana (2010). Penilaian Hasil Proses Belajar Mengajar. (cet : XV). Bandung: PT Remaja Rosdakarya.

Suprijono (2010). Cooperatif Learning ; Teori dan Aplikasi PALKEM. Yogyakarta : Pustaka Pelajar.

Syah, Muhibbin. (2009). Psikologi Pendidikan dengan Pendekatan Baru. Bandung: Remaja Rosdakarya.

Trianto. (2011). Mendesain Model Pembelajaran Inovatif-Progresif. Jakarta: Kencana

Winkel (1999). Psikologi Pengajaran. Jakarta : PT Grasindo. 
Jurnal Pendidikan Teknologi dan Kejuruan: Vol. 19 No. 2 November 2017 